Digitalizacja archiwalnych numerów czasopisma naukowego Analecta Cracoviensia 1-24 (1969-1992) i ich publikacja w otwartym dostępie - zadanie finansowane w ramach umowy 672/P-DUN/2017 ze środków Ministra Nauki i Szkolnịctwa Wyższego przeznaczonych na działalność upowszechniającą naukę

\title{
MIĘDZY SKUTECZNOŚCIĄ A OBJAWIENIEM Przemiana starożytnej filozofii historii
}

W r. 382 cesarz Gracjan nakazał usunąć posąg bogini Wiktorii z sali posiedzeń rzymskiego senatu. Jednocześnie zabronil przekazywania w testamentach sum na rzecz starych pogańskich kultów, a na westalki nałożył obowiązek płacenia podatków. Te zarządzenia boleśnie ugodziły dawne kulty. Nie było to bowiem jakby zwyczajne ukłucie igłą, gdyż owe zarządzenia ujawniły zaostrzanie się metod postępowania rzymskich cesarzy wobec pogaństwa. Początkowa tolerancja, praktykowana przez dynastię Konstantyna Wielkiego, została zastąpiona przez polityczną kalkulację (od czasów Konstancjusza II) i wyraźne popieranie chrześcijaństwa. Dwa lata wcześniej chrześcijaństwo zostało ogłoszone religią państwową ${ }^{1}$.

Usunięcie ołtarza boginii Wiktorii z sali posiedzeń senatu rzymskiego było ponadto aktem politycznym o niezwykle symbolicznym znaczeniu. Dotąd bowiem rozpoczynano posiedzenia senatu od złożenia ofiary dla bogini i ta obecność pogańskiego bóstwa nadawała postanowieniom senatu religijną jakość. Senat wszakże, choć już dawno temu stracił swoją władzę polityczną, to jednak jako reprezentant miasta Rzymu był instytucją, której przysługiwało najwyższe poważanie i moralno-religijny autorytet. W przeważającej części był on wówczas jeszcze pogański, więc też usunięcie ołtarza bogíni Wiktorii było nie tylko zwykłą zapowiedzią walki, lecz także publicznym pozbawieniem senatu wszelkiej mocy działania.

W sporze o oltarz boginii Wiktorii, toczonym przy pomocy argumentów politycznych i teologicznych przez obydwu rzeczników starej i nowej religii, tzn. przez Kwintusa Aureliusza Symmachusa ${ }^{2}-\mathrm{w}$ interesie pogaństwa, i przez biskupa Ambrożego - w interesie wiary chrześcijańskiej, nie chodziło

* Poniższy tekst jest przekładem referatu wygłoszonego w Papieskiej Akademii Teologicznej w Krakowie dnia 6 maja 1988. W wersji oryginalnej artykuł ten ukazal się w: Handbuch der Fundamentaltheologie, hrsg. von W. Kern, H. J. Pot t m e yer, M. Se ckle r, Bd. 4, Freiburg 1988, s. $317-333$.

${ }^{1}$ Zob. edykt Teodosiusza I Cunctos populos z 28 II 380 (Codex Theodosianus 16, 1, 2).

2 Zob. R. Kle in, Symmachus. Eine tragische Gestalt des ausgehenden Heidentums, Darmstadt 1971; tenże, Der Streit um den Victoriaaltar, Darmstadt 1972 (Texte zur Forschung, 7). 
jedynie o kwestie polityczne, a mianowicie czy rozpoczęta przez dynastię Konstantyna tolerancja religijna ma być nadal kontynuowana. Ten konflikt sięgał głębiej. Toczyła się bowiem dyskusja wokól właściwej definicji pojęcia historii i pojęcia prawdziwego Boga. Wprawdzie Symmachus, jako prefekt Rzymu i jedna z czołowych osobistości w senacie, żądał już tylko religijnej tolerancji, a na marginesie tego dawał do zrozumienia, że sam czuje się przedstawicielem prawdziwej religii, to jednak jako relacja dla Walentyniana II pozwala wysnuć wniosek, iż jej autor zawodzi jedynie łabędzi śpiew nad ginącym pogaństwem. Kiedy się spojrzy na spór Symmachusa i Ambrożego, wówczas z łatwością odkrywa się wszystkie te elementy, jakie ponownie wystąpią po r. $410 \mathrm{w}$ teologicznej dyskusji św. Augustyna z przedstawicielami dawnej wiary. Można zatem przyjąć, że dyskusja wokól sprawy ołtarza bogini Wiktorii była uzasadnionym wstępem do augustyńskiej koncepcji historii ${ }^{3}$. $\mathrm{II}^{4}$ :

Na początku swojej relacji formułuje Symmachus prośbę do Walentyniana

Prosimy zatem, abyś przywrócił religię w tym kształcie, w jakim tak długo służyła ona państwu. Oczywiście można by wyliczać władców o takiej czy innej orientacji religijnej, z takim czy innym nastawieniem. Dawniejsi władcy uczestniczyli wszakże w zwyczajach ojców, a ich następcy nie znieśli tych zwyczajów. Jeżeli nie bierzesz sobie na wzór religii dawniejszych władców, to przynajmniej z wyrozumiałością traktuj tę ostatnią.

I żeby dosadniej podkreślić swoją prośbę, apeluje w błagalnym tonie do Walentyniana II, powołując się na jego ojca: „Ten ubóstwiany starzec patrzy z wysokości gwiazd na łzy kapłanów i widzi, że się go obwinia o to, iż został naruszony zwyczaj, przezeń chętnie zachowywany" 5 .

Symmachus agrumentuje zupełnie w sensie antycznego myślenia historycznego. Istniejące stosunki można poprawić, o ile się będzie unikać dawnych błędów i naśladować dawne osiągnięcia. „Czyjś nieopatrzny krok w przeszłości poucza tego, kto potem przychodzi. Krytyka zaś poprzedniego wypadku przyczynia się do ulepszenia czegoś analogicznego"6. To, czego żąda Symmachus, sprowadza się do wyciągania nauki z historii. Jego dowodzenie wskazuje na związek przyczynowy i wypływające z niego wartościowanie. Wywodzi on, że kulty naruszone przez Gracjana rozwijały się uprzednio zupełnie swobodnie. Dzięki temu cesarstwo rzymskie stało się wielkie i zachowało swą moc. Jak długo tradycyjne kulty były uprawiane, tak długo w państwie panował dobrobyt. Dlatego jest rzeczą nierozsądną usuwać bez namysłu te kulty.

Każdy ma swój własny obyczaj i swój rodzaj wiary. Boski duch przydzielił miastom rozmaite kulty do ich ochrony. Jak czlowiek otrzymuje przy urodzeniu duszę, tak i ludy otrzymują bóstwa opiekuńcze ich przeznaczenia. Do tego dochodzi korzyść, najbardziej lącząca ludzi

${ }^{3}$ Odnosi się to do zniweczenia rzymskiej historii, aczkolwiek apologetyczny spór z Augustynem zawiera inną jakość.

${ }^{4}$ R. Kle in, Der Streit..., s. 101 (3 rel. 3).

5 Tamże, s. 113 (3 rel. 20).

${ }^{6}$ Tamże, s. 103 (3 rel. 6). 
i bogów. Ponieważ każde wyjaśnienie rozumowe pozostaje niejasne, cóż bardziej uprawnia nas do poznawania mocy bogów, jeśli nie pamięć na ich błogosławioną pomoc i wyraźne skutki ich interwencji? Jeżeli jakaś religia cieszy się przez dlugi czas uznaniem, przeto powinniśmy tak wielu pokoleniom dochować wierności i pójść w ślady naszych ojców, wszak oni — dla swego dobra - poszli z kolei za swoimi? .

Symmachus uzasadnia trwanie przy starym kulcie z racji jego skuteczności. Podkreśla wyraźnie, że jemu nie chodzi wprost o religię, lecz o zasadę. „Nikt nie powinien uważać, że bronię jedynie sprawy religii. Takie postępowanie spowodowało w świecie rzymskim wiele nieprawości"8. Jako przykład naruszenia tej zasady (zachowanie kultu z racji jego skuteczności) przytacza Symmachus złe zbiory w minionym roku:

Winę za to nie ponosi gleba. Nie wolno nam także oskarżać o to południowego wiatru. Żaden mróz nie wyrządził szkody w zasiewach, żadne chwasty nie zagłuszyły dojrzałych zbóż na polach; wyłącznie bluźnierstwa przeciwko bogom sprowadziły na nas suszę w tym roku. Nie można było zapobiec temu, aby wszyscy ludzie nie utracili tego, czego odmówiono naszej religii. Cofnięcie dotacji na utrzymanie świątyń miało ten skutek, że nieurodzaj zapanował w kraju, prowincjom doskwierał niedostatek, państwo nie mogło wypłacić żołdu żołnierzom ${ }^{9}$.

Nie wymieniono tu, ale to się czuje, że z tego również powodu zginął w powstaniu brat Gracjana. Po tych przykładach powraca Symmachus raz jeszcze do swojej zasady:

Kiedy otrzęsiono dęby [z żołędzi], aby ludzi utrzymać przy życiu, kiedy korzonki ziół powyrywano z ziemi, kiedy nieurodzaj w pewnych okolicach nie został wyrównany przez bogate zbiory w innych krainach, jakże jeszcze miano się troszczyć o lud i święte dziewice? Utrzymanie, jakiego odmówiono zarządcom świątyń, gwarantowało dobre zbiory na całym okręgu ziemi i dlatego było ono raczej zabezpieczeniem przed nieszczęściem, a nie dowodem zwykłej wspaniałomyślności. Któż może w to wątpić, że w interesie powszechnego dobrobytu dawano im to, za odebranie czego bogowie ukarali nas teraz powszechną biedą ${ }^{10}$

W tej argumentacji wychodzi Symmachus niewątpliwie z założenia, że jednakowe przyczyny prowadzą do jednakowych skutków. Jeśli to jest przesłanką historycznej prawidłowości, to nie potrzeba się już dalej rozwodzić nad tym, jakie skutki w przyszłości spowoduje dla rzymskiego państwa polityka nieprzestrzegania tradycyjnych kultów.

Odpowiedź Ambrożego, Symmachowego oponenta, została nam przekazana w jego 18. liście do cesarza Walentyniana. Ten były konsul z Ligurii, teraz w szatach katolickiego biskupa, znał dokładnie rzymskie myślenie z racji swe-

\footnotetext{
${ }^{7}$ Tamże, s. 105 (3 rel. 8).

${ }^{8}$ Tamże, s. 109 ( 3 rel. 15$)$.

9 Tamże, s. 111 (3 rel. 16).

${ }^{10}$ Tamże, s. 111 (3 rel. 17).
} 
go pochodzenia. I z tym rzymskim myśleniem, jak zobaczymy, pozostanie on nadal związany. Jest sprawą niezmiernie frapującą prześledzić, jak Ambroży — w stosunku do Augustyna - zajmuje pośrednie miejsce między rzymskim patriotyzmem a jego chrześcijańskim odrzuceniem ${ }^{11}$.

W gruncie rzeczy Ambroży zgadza się z Symmachusem co do tego, że cesarz rzymski powinien się kierować w swych decyzjach dobrem państwa. Stara się on zatem zbadać, czy żądana przez Symmachusa tolerancja w odniesieniu do dawnych rytów korzystniejsza jest dla dobrobytu państwa aniżeli ich tępienie. Stanowisko zajęte następnie przez Ambrożego wobec poglądów Symmachusa jest dziedzictwem chrześcijańskiej apologetyki od czasów Tertuliana i nie rości sobie ono prawa do oryginalności ${ }^{12}$.

Pierwszy argument, wysunięty przeciwko Symmachusowi, kwestionuje powoływanie się na skuteczność [kultu]. To co Symmachus nazywa powodzeniem, Ambroży przedstawia w satyrycznym opisie jako niepowodzenie. Jeśli bowiem dawni bogowie przyczyniali się do zwycięstw, to należałoby ich także uczynić odpowiedzialnymi za klęski. Jeśli bogowie pokonali Brennusa i Hannibala, to dlaczego ci sami bogowie postawili wówczas Rzymian wobec faktu, że ich wrogowie dotarli aż do murów Rzymu?

Te ofiary, powiada Symmachus, strąciły Hannibala z naszych murów, a Senonów z Kapitolu. Lecz sławiąc moc tych ofiar, zdradza on ich słabość. Otóż Hannibal szydzil przez długi czas z rzymskich ofiar i zwycięsko dotarł aż do murów Miasta, chociaż bogowie stanęli z nim do walki. Dlaczegóż więc Rzymianie musieli znosić oblężenie, skoro bogowie orężnie walczyli w ich obronie. A cóż tam powiedzieć o Senonach? Kiedy usiłowali wtargnąć do środka samego Kapitolu, garstka rzymskiej armii nie zdołałaby ich powstrzymać, gdyby gęsi nie zdradziły napastników swoim gwałtownym gęganiem. Patrzcie, jakich to strażników mają rzymskie świątynie! Gdzież był wtedy Jupiter? Czyżby przemówił on wówczas głosem jakiejś tam gęsi? ${ }^{13}$

To karykaturalne przedstawienie rzymskich dziejów miało na celu wykazać, że polityka pogańskiej epoki nie może być uznana w żaden sposób za pełną sukcesów. Można się zgodzić na jej pewne osiągnięcia w początkowym okresie, jako że żaden apolegeta nie może zaprzeczyć, iż pax Romana miała błogosławione działanie. Musimy się nawet zgodzić $\mathrm{z}$ tym, że imperium rzymskie przygotowało grunt dla Ewangelii na Wschodzie. W tym przeto sensie argumentacja Ambrożego pozostaje niespójna.

Ambroży musiał więc głębiej sięgnąć i zabral się do tego w ten sposób, że w następnym podejściu zaprzeczył, jakoby istniał związek przyczynowy między czcią oddawaną bogom a powodzeniem w życiu. Powodzenia i niepowodzenia ludzkiego życia nie są w ogóle dziełem bogów, a tylko zdarzeniami wy-

${ }^{11}$ Por. R. P a s c h ou d, Roma aeterna. Etudes sur le patriotisme romain dans l'occident latin à l'époque des grandes invasions, Neuchâtel 1967.

12 Zob. W. G e e rling s, Apologetik, [w:] Handbuch der Fundamentaltheologie, Bd. 4, Freiburg 1988 , s. $320 \mathrm{nn}$.

${ }^{13}$ R. Kle in, Der Streit..., s. 133 (ep. 18, 4 n.). 
stępującymi na co dzień. Podnoszony z emfazą przez Symmachusa głód w minionym roku ma naturalne przyczyny. „Czyż jest ktoś tak bardzo nieświadom tego, co się człowiekowi przytrafia, że dziwi się zmienności lat?" ${ }^{14}$ Ponieważ rozmaite prowincje zebrały rozmaite plony, dowodzi on przeto:

A więc miniony rok wcale nie ucierpial przez suszę z powodu bluźnierstw miotanych na bogów, obecny zaś doznał obfitości owoców nie [z powodu] wiary. Czy chciałby ktoś zaprzeczyć, że winne krzewy niezwykle obrodziły. Znowu zwieźliśmy plon, który okazal się bogatszy niż oczekiwano i cieszymy się, że jeszcze obfitsze winobranie niż poprzednio przyniosło nam zysk ${ }^{15}$.

Plony istotnie zależą od tego, z jaką zręcznością rolnik uprawia pole. „Dawniej ziemia nie umiała jeszcze pomnażać swej płodności. Później jednak, kiedy zapobiegliwy rolnik zaczął pola uprawiać i bezkształtną glebę obsadzać winnicami, wówczas porzuciła ona swój dziki wygląd, lagodnie usposobiona przez wprawne pielęgnowanie"16. Dobrobyt codziennego życia zależy więc od umiejętności chłopów i rzemieślników, a polityczna wielkość Rzymu zależy nie od bogów, lecz od męstwa legionów: „W równiej mierze wierzyli oni, że Wiktoria jest boginią, która na pewno jest darem, a nie władzą; ona bowiem, skoro jest darem, nie sprawuje władzy, a dar ten jest rezultatem nie jego mocy religijnej, lecz dzielności legionów"17.

Argumentacja Ambrożego sprowadza się jednoznacznie do sekularyzacji polityki. Jest rzeczą oczywistą, że zajmuje się on tą sekularyzacją, aby ukazać własnego chrześcijańskiego Boga, jako pana wszelkich dziejów, i odrzucić poszczególnych kompetencyjnych bogów rzymskich. By sprostać poziomowi argumentacji Symmachusa, musial Ambroży użyć argumentów świadczących o politycznej i gospodarczej wyższości chrześcijańskiego Boga. Wobec niezaprzeczalnych politycznych kłopotów i objawów rozpadu rzymskiego cesarstwa uważa się Ambroży za niezdolnego do takiej argumentacji. Dlatego w konsekwencji musi wyrzucić za burtę sformułowaną przez Symmachusa zasadę skuteczności starych kultów. W jej miejsce, zgrabnie nawiązując do poglądów Symmachusa, formułuje swoją zasadę objawienia. Symmachus argumentował: „Ponieważ każde wyjaśnienie rozumowe pozostaje niejasne, cóż bardziej uprawnia nas do poznawania mocy bogów, jeżeli nie pamięć na ich błogosławioną pomoc i wyraźne sukcesy? Jeżli jakaś religia cieszy się przez długi czas uznaniem, to powinniśmy dochować wierności tak wielu pokoleniom i pójść za naszymi ojcami, którzy dla własnego dobra poszli za swoimi ${ }^{18}$. W konsekwencji domagał się Symmachus: „Na jednej drodze nie można dojść do zrozumie-

14 Tamże, s. 147 (ep. 18, 21).

15 Tamże.

${ }^{16}$ Tamże, s. 149 (ep. 18, 25).

17 Tamże, s. 153 (ep. 18, 30). tność.

${ }^{18}$ Tamże, s. 105 (3 rel. 8). Według Symmachusa, kryterium prawdziwości religii jest jej stroży- 
nia tak wielkiej tajemnicy"19. Tolerancja jest zatem wyjściem z zakazanego poglądu na działanie wyższych sił i historii.

W tym miejscu Ambroży wysunął swój najsilniejszy argument ${ }^{20}$ :

Do zrozumienia tak wielkiej tajemnicy nie można dojść tylko na jednej drodze, powiada Symmachus. Ale my chrześcijanie wiemy z ust Bożych to, czego wy nie wiecie. To, co wy chcecie wiedzieć w niejasnych zarysach, my tę wiedzę mamy zupełnie pewną dzięki mądrości i prawdzie Bożej. Dlatego wasze postępowanie nie zgadza się z naszym. Wy błagacie cesarza o pokój dla waszych bógów, my natomiast prosimy Chrystusa o pokój dla cesarza. Wy oddajecie cześć boską dziełu waszych rąk, my uważamy za głupotę uznawać za Boga wszystko, co można wytworzyć przy pomocy rąk, gdyż Bóg nie życzy sobie, aby go czczono w kamieniach. W końcu przecież nawet wasi filozofowie wykpili ten zabobon.

Niejasnemu pojęciu bóstwa u pogan przeciwstawia Ambroży wyraźne posiadanie prawdy objawionej przez chrześcijan. Jeżeli zaś Symmachus domaga się od cesarzy ochrony dla bogów, to Ambroży pokazuje, że Chrystus obdarza cesarzy pokojem. Pomoc, o jaką zabiega Symmachus dla dawnych bogów, zostaje więc przeniesiona na nowego Boga. Dawni bogowie okazali się nieudolni (zasada skuteczności została tu raz jeszcze sprowadzona do absurdu), nowy Bóg - Chrystus - jest dawcą pokoju. Już później będzie Orozjusz nawet dowodził że Chrystus był tym, który uratował Rzym od Hannibala ${ }^{21}$.

Ambroży rezygnuje z przeprowadzenia dowodu prawdziwej religii. Wyrósł więc znacznie ponad apologetyczną sytuację. Odrzuca on pojmowanie historii w stylu, w jakim czynią to jego przeciwnicy. Argumentację Symmachusa pozbawia podstaw, zastępując zasadę skuteczności zasadą objawienia. Obaj mogą przytaczać argumenty $z$ historii, ale objawieniem dysponuje jedynie chrześcijanin. Ambroży mógł zrezygnować z porozumienia ze swoim oponentem, ponieważ był pewny, że nie zdoła go przekonać. W swoim liście szło mu tylko o to, aby pozyskać dla siebie cesarza jako wiernego syna Kościoła.

Rozprawiwszy się z zasadą skuteczności i związaną z nią zasadą kompetencyjności bogów, Ambroży może teraz przystąpić do sformułowania na nowo teorii exemplów, istotnego składnika tej interpretacji historycznej. Zachowanie tego, co się sprawdziło, skierowane zostało na exempla i znajduje swój wyraz w ich przekazie. Kto chce zniweczyć zasadę skuteczności, musi ustalić nową funkcję przykładów. Ponieważ ani teoria wychowania, ani interpretacja historyczna nie mogą się rozprzestrzeniać bez exemplów, przeto obie muszą podjąć także zmianę funkcji exemplów.

Rola exemplów w ujmowaniu dziejów rzymskich została zwięźle zarysowana przez Cicerona. Sformułował on maksymę politycznego działania: „Niczego nowego nie wolno wprowadzać wbrew przykładom i ustaleniom przod-

${ }^{19}$ Tamże, s. 107 (3 rel. 10).

20 Tamże, s. 135 n. (ep. 18,8).

21 Orosiu s, Historiae adversus paganos, IV 17,8 - 11 (CSEL 5 s. 253). Na temat Orozjusza zob.: H. W. Goe t z, Die Geschichtstheologie des Orosius, Darmstadt 1980. 
ków"22. Albowiem obyczaje i ustanowienia wprowadzone przez przodków uczyniły wielkim państwo rzymskie i dlatego są one dla każdego zobowiązującym wzorcem. Cicero wszakże wskazuje nie na niewolnicze naśladownictwo takiego wzorca, lecz dokonuje rozróżnienia między tym, co przodkowie dokonali, a powodami tych dokonań: „Nie można więc tak po prostu iść za przykładem przodków, lecz musi się ukazać przyczyny, które leżały u podstaw owych przykładów"23. Powoływanie się na exempla i mos maiorum zmierza do wywołania stabilnego, zrównoważonego politycznie działania. Bierze się to $\mathrm{z}$ teorii historycznej, że to samo działanie w tych samych warunkach daje ten sam skutek: sukces lub niepowodzenie. Ponieważ exempla opisują tylko paradygmatycznie mały odcinek historycznego procesu, przeto teoria wychowania domaga się sporządzenia bez mała zbioru przykładów, aby w ogóle można było pisać historię. Dziejopisarstwo i retoryka układają więc wielkie zbiory przykładów, $\mathrm{z}$ których powstaje niemal kanon ${ }^{24}$. Z pomocą tego kanonu przykładów można następnie wychowywać ludzi, a także interpretować historię. Taka interpretacja historii jest w ścisłym znaczeniu konserwatywna, ponieważ to wymaga tylko postępu (Cicero). O wiele bardziej decydujące jest naśladownictwo tego, co już się stało (sukces). Konserwatywna interpretacja historii ukierunkowana na exempla, a nie na postęp, dostosowuje się przez to bez uszczerbku do rzymskiego pojęcia religii. Także ono bowiem zna wielu pojedynczych, nie mówiących bogów, odpowiedzialnych za drobiazgi, stosowne procesowi historycznemu, rozczłonkowanemu na exempla.

Tym, co w chrześcijańskiej interpretacji historii jest zdecydowanie nowe jak to już wykazano przy Ambrożym - to usunięcie rozczłonkowania historii na korzyść jednego podmiotu historycznego, a mianowicie - Jezusa Chrystusa, i związana z tym deprecjacja przykładów. Zanim do tego doszło, tradycja chrześcijańska posługiwała się jednak bardzo wieloma przykładami cnoty. Ten proces recepcji możemy $\mathrm{z}$ całą dokładnością prześledzić $\mathrm{w}$ dziełach dwóch przedstawicieli ówczesnego chrześcijaństwa: Tertuliana i Ambrożego.

Bogata tradycja pojęcia exemplum przeszła względnie wcześnie i prawie bez uszczerbku do nauczania kościelnego. Sam Jezus jawił się po prostu ludziom jako wzorzec, a nowotestamentalne pisma rozumiały chrześcijańskie życie jako naśladowanie tego wzorca. W ten sposób pogańska tradycja dotycząca exemplum użyczyła praktycznego narzędzia poglądowemu nauczaniu kościelnemu, co bardzo ułatwiło sformułowanie pojęcia przykładu. Tertulian, pierwszy wybitny łaciński teolog, człowiek o gruntownej znajomości klasycznej tradycji, co upoważniało go do rozprawienia się z pogańską religią, posłu-

${ }^{22}$ M. T. Cice ro, De imperio Cn. Pompei ad quirites oratio, 10 (60).

${ }^{23}$ M. T. Cic e ro, Philippica IX 1,3: Non igitur exempla maiorum quaerenda, sed concilium est eorum, a quo ipsa exempla nata sunt, explicandum.

${ }_{24}$ Zob. H. K o r n h a rd t, Exemplum. Eine bedeutungsgeschichtliche Studie, Leipzig 1936; A. Lu m pe, Exemplum, [w:] Reallexikon für Antike und Christentum, t. 6 s. 1229 - 1257. 
guje się obficie dostępnymi mu przykładami ${ }^{25}$. Także dla niego Chrystus jest po prostu wzorcem. Wcześniejsze przykłady, zarówno ze Starego Testamentu, jak i z rzymskiej historii, nie mogą stanowić dla uwolnionych spod prawa, jako też dla nawróconych z pogaństwa, żadnego wystarczającego, charakterystycznego wzorca. Skoro sam Chrystus pokazał swoim, jak powinni żyć, przeto Tertulian uznaje za regułę: „Ex forma dominica agere debetis”26. W ścisłym znaczeniu, sam Bóg jest pierwszym przykładem. Jednakże Bóg jest daleki i nieprzystępny, przeto użyczył nam latwo zrozumiałego przykładu swego Syna Jezusa. Podczas gdy inni filozofowie nauczali bezskutecznie, to przykład Jezusa zawiera w sobie właśnie dopełnienie tej nauki. Dlatego można posługiwać się przykładami, a w pracy pedagogicznej są one nieodzowne.

$\mathrm{Z}$ tej też racji dokonuje Tertulian rozróżnienia między exempla vetera i exempla nova ${ }^{27}$. Exempla vetera to dla niego wielkie postacie Starego Testamentu. Sa to exempla domestica albo exempla interna ${ }^{28}$, w przeciwieństwie do exempla profana ${ }^{29}$ pogańskiej historii. Exempla profana użyczają jedynie analogii do właściwie pojętego chrześcijańskiego przykładu. Przy pomocy analogii ex minoribus an maiora wprowadza on przykłady $\mathrm{z}$ dziejów rzymskich. Te bowiem są na zawstydzenie złych chrześcijan. Jeżeli już poganie wykazywali takie cnoty, aby się diabłu przypodobać, to czymże dopiero powinni się wykazać chrześcijanie dla Bożej czci? ${ }^{30}$ Pod tym względem zna Tertulian całą masę rzymskich przykładów i po mistrzowsku wprowadza tę rzymską tradycję także do swojej pedagogicznej argumentacji. Otóż jak w świeckiej literaturze łacińskiej obowiązywały określone topoi (surowość obyczajów Katona, ubóstwo Fabrycjusza, łagodne panowanie Regulusa), tak teraz w ich miejsce wstępują chrześcijańskie topoi. Tertulian oddziaływuje tu także na kształtowanie poglądów: wiara Abrahama, pokuta Dawida, cierpliwość Hioba. Te exempla vetera Starego Testamentu uzupełnia innymi z Nowego Testamentu. Obok wybijającego się przykładu Chrystusa są to przede wszystkim apostołowie i męczennicy, właściwe wzory do naśladownictwa dla dzisiejszych chrześcijan.

Jeżeli jeszcze Tertulian żył prawie całkiem pod urokiem kultury pogańskiej i w ciągłych z nią utarczkach musiał okazać się skuteczny, to w Ambrożym, kolejnym wielkim dziedzictwie tej tradycji, jawi nam się samoświadomość biskupa, który zna już świat ukształtowany przed nim po chrześcijańsku ${ }^{31}$. Jest to przywódca, w niczym nie ustępujący przeważającej pogańskiej elicie szlacheckiej, a nawet czujący, że ją przewyższa świadomością przynależności do innego świata. Jako wykształcony Rzymianin zna swoją tradycję i pozwala się przez

${ }^{25} \mathrm{Na}$ temat Tertuliana pisze: W. Ge e rling s, Christus Exemplum, Mainz 1978, s. 159-164.

26 Te rtulia n, De idolatria 18,5 (CCL 2 s. 1119).

27 Zob. tegoż, De exhortatione castitatis 13 (CCL 2 s. 1033 n.).

${ }^{28}$ Tamże.

${ }^{29}$ Por. zwlaszcza Apologetyk i Ad nationes.

${ }^{30}$ Te rt ulian, De exhortatione castitatis, 13.

${ }^{31}$ Zob. W. Ge e r ling s, Christus Exemplum...,s. 164-168; E. D a s s m a n n, Die Frömmigkeit des Kirchenvaters Ambrosius von Mailand, Münster 1965. 
nią inspirować, jednakże przekonywająca jest dla niego tylko tradycja chrześcijańska. Wyraźnie odcina się od pogańskiej filozofii i pogańskich przykładów. Przeciwieństwo: „haec illi... nos autem”32, rozgranicza chrześcijańską mądrość od pogańskiej filozofii. $\mathrm{Z}$ tej też racji pogańskie exempla, może z wyjątkiem tego o Fabrycjuszu, nie znajdują w jego oczach żadnego uznania ${ }^{33}$. Przeciwnie, stawia wyraźny postulat: „redeamus ad nostrum Moysen”34. Pogańskie exempla są przez niego systematycznie pomniejszane, co na pewno da się częściowo wytłumaczyć faktem jego utarczek z pogańską elitą społeczną i doświadczeń przy próbie przywrócenia pogaństwa przez Juliana Apostatę. Ten bowiem próbował przeciwstawić się chrześcijaństwu właśnie poprzez położenie nacisku na tradycyjne rzymskie ideały i cnoty. Jeśli Cicero mówi o mos maiorum, to wie, że ów mos uwidačznia się w przykładach. Również Ambroży mówi całkiem świadomie o przykładach przodków, ale ma na myśli biblijne postacie. Simplex veritas piscatorum jest jego efektownym przeciwstawieniem do verba philosophorum ${ }^{35}$. Kościół Chrystusowy może służyć własnymi przykładami i wcale nie jest zdany na exempla rzymskiej tradycji. Występującemu już u Tertuliana przeciwstawieniu słowa i prawdy, słowa i czynu ${ }^{36}$ nadaje Ambroży raz jeszcze szczególne znaczenie, uwydatniając identyczność teorii i praktyki w chrześcijańskich przykładach ${ }^{37}$. Klasyczna pogańska tradycja zostaje oczerniona z powodu rozdźwięku między teorią i praktyką oraz nieskuteczności przykładów. Uwzględnianie przykładów z własnej historii opiera się przede wszystkim na dokładnej wiedzy o historycznej ciągłości i samoświadomości kościelnej wspólnoty. U Ambrożego ta ciągłość została zakotwiczona we wiedzy o zbawczo-historycznej odpowiedzialności Starego i Nowego Testamentu. Dzięki tej pewności może on sięgać po pogańską tradycję tam, gdzie mu to odpowiada. Gdzie zaś jest mu ona niepotrzebna, a to zdarza się najczęściej, całkiem zwyczajnie ją ignoruje lub dyskredytuje.

Sposób, w jaki Ambroży obchodzi się z przykładami pogańskiej historii, dobitnie wskazuje na umocnienie samoświadomości Chrystusowego Kościoła. Kościół ma własne exempla, nie jest już zdany na pogańskie przykłady, w razie potrzeby może owe pogańskie exempla przytoczyć. Własnego wkładu do teorii exemplum Ambroży nie wniósł. Zasługą jego wszakże było to, że w wybuchowej sytuacji historycznej ukazał jałowość rzymskich przykładów. To osiągnięcie jest o tyle istotne, gdyż było wstępnym warunkiem nowej koncepcji exemplum i historii, koncepcji sformułowanej później przez Augustyna.

${ }^{32}$ A m brosius, De officiis ministrorum, I 9 (PL 16 s. 35).

${ }^{33}$ Tamże, III 15, 91 (PL 16 s. 180).

${ }^{34}$ Tamże.

35 A m brosius, De incarnationis dominicae sacramento, 9,89 (PL 16 s. 876); por. H. H age $\mathrm{n}$ a h l, Piscatorice et non aristotelice. Zu einem Schlagwort bei den Kirchenvätern, [w:] Septentrionalia et orientalia. Studia Bernhardo Karlgren dedicata, Stockholm 1959, s. 184 - 193.

${ }^{36}$ A m brosius, De Abraham I 2,4 (CSEL 32,1 s. 503).

${ }^{37}$ Zob. G. Ma de c, Saint Ambroise et la philosophie, Paris 1974, s. 184. 
Rezerwa, z jaką bp Ambroży traktowal pogańskie exempla, daje się łatwo wytłumaczyć, kiedy uwzględnimy stanowisko zajęte przezeń wobec Symmachusa. Posługiwanie się argumentami przy zajmowaniu się historią pozwoliło Ambrożemu osiągnąć raczej postępowy jej obraz. Po prostu nie należy więcej naśladować dawnych przykładów, albowiem rozstrzygający przykład Chrystusa i nova exempla chrześcijańskiego Kościoła są wzorcem. Stopień uznania zbawczej roli Chrystusa jest teraz miernikiem ważności exemplów. Wartość exemplum zależy od jego bliskości z Chrystusem. Skierowanie poszczególnych przykładów na Chrystusa ma swoje wewnętrzne uzasanienie w tym, że w historii istnieje tylko jeden Bóg działający przez Chrystusa, a nie bogowie podzieleni wedle kompetencji, do których odnoszą się liczne exempla. Dlatego też przekształcenie antycznego pojęcia exemplum i zmiana ujęcia historii zostały umotywowane nie tylko w antypogańskim apologetycznym stanowisku Ambrożego, lecz także otrzymały swoje wewnętrzne uzasadnienie w nowym ujęciu Boga.

O ile biskup Ambroży przyznaje historii jeszcze względną niezależność i zbawczo-pedagogiczne znaczenie, to ta opinia zmienia się, gdy spojrzymy na wielkiego Afrykańczyka - Augustyna. Daje się tu zaobserwować pewien proces, rozwijający się od względnie wysokiej oceny pogańskich przykładów u Tertuliana, poprzez ograniczenie ich znaczenia u Ambrożego, do radykalnego ich odrzucenia przez Augustyna ${ }^{38}$.

Jeśli Ambroży argumentowal jeszcze przy pomocy historii i historycznych przykładów, to u Augustyna ten rodzaj argumentacji ustępuje miejsca lekceważeniu historii. W swoim dziele De diversis quaestionibus $L X X X I I I$ notuje on pod kwestią $48^{39}$ :

Cóż jest godne wiary? Istnieją trzy rodzaje rzeczy wiarogodnych. W jedne wierzy się zawsze, chociaż nikt nigdy ich nie rozumie; jest to każda historia, która przenika czasowe i ludzkie wydarzenia. Inne rzeczy rozumie się natychmiast, gdy tylko się w nie wierzy; są to wszystkie ludzkie wnioski rozumowe co do liczb lub innych przedmiotów nauki. W trzeci rodzaj rzeczy wierzy się najpierw, aby je potem zrozumieć; do nich należy Boska rzeczywistość, zrozumiana tylko przez tych, którzy są czystego serca. Do takiego czystego serca dochodzi się wylącznie poprzez zachowywanie przykazań, bo tych celem jest prawe życie.

Wedle tego poglądu Augustyna historia została zatem pozbawiona zrozumienia: „Numquam intelliguntur sicut est omnis historia”40. Skoro to dotyczy zasadniczo historii, to również dotyczy historycznych przykładów. Dlatego stają się one niezbędne. Augustyn przyznaje im ważną pedagogiczną funkcję w ramach wychowania, nawet dla dziejów wiary nie są one bez znaczenia. Ponieważ nie można ze zrozumieniem wniknąć w historyczne exempla, nie można również poznać ich wewnętrznej motywacji. Cicero — poganin żądal ponadto,

38 Zob. W. Ge e rlings, Christus Exemplum..., s. 209-221.

39 A u gu st y nu s, De diversis quaestionibus $L X X X I I I$, q. 48 (CCL 44a s. 75)

40 Tamże. 
tywami). Dla chrześcijanina Augustyna ta wewnętrzna motywacja nie jest poznawalna, ponieważ jest ona także częścią historii:

Oto widzicie, jak wielkie dzieła tworzy pycha. Zachowajcie głęboko w sercach swoich, jak jest porównywalne to, co tworzy pycha, z tym co tworzy miłość. Głodnego żywi się z miłości, ale także żywi się go z pychy; miłość wielbiąca Boga, ale i pycha wielbiąca samą siebie; miłość okrywa nagiego, okrywa go też pycha; z miłości można pościć, także przez pychę można pościć; z miłości grzebie się zmarłych, jako i z pychy. Wszystkie dobre dzieła, jakie byś chcial wymienić, czyni miłość, lecz w równej mierze dokonuje ich także pycha [...] My widzimy tylko dzieła [...] w dziełach niczego nie można rozróżnić ${ }^{41}$.

Rola exemplum zostaje tu zredukowana do ostentacyjnego przedstawienia zbawczego przykładu Jezusa Chrystusa. Exemplum w żaden sposób nie wystarcza do spowodowania zbawczego procesu człowieka. Zwłaszcza w antypelagiańskim sporze żąda Augustyn, aby exemplum zostało uzupełnione przez adiutorium lub sacramentum ${ }^{42}$. Patrząc $\mathrm{z}$ tego punktu widzenia, Augustynowe dzieło De civitate Dei jest najradykalniejszą apologią w czasach starożytnych. Nikt nie ważył się tak zdecydowanie zniweczyć rzymskie exempla, jak Augustyn. Tylko on ośmielił się mówić o cnotach pogan jako o „poniekąd błyszczących występkach" 43 . Żadnemu z poprzednich apologetów nie przyszło do głowy podać w wątpliwość niewinność Lukrecji, pod adresem której Augustyn czyni niejasne aluzje. $\mathrm{Z}$ zajętej przezeń antypelagiańskiej postawy wynika w konsekwencji dla niego, że nie może istnieć żadna pewność wynikająca z cnoty. Z kolei nikt tak jak on nie podważył zasady skuteczności pogańskich kultów na korzyść zasady objawienia. W związku z tym można tylko napomknąć, że Augustyn broni niezwykłego pojęcia Boga i każda myśl o „kompetencjach" jest mu obca.

W kontrowersji Ambrożego z Symmachusem pobrzmiewało poniekąd preludium tego, co miało nastąpić. Podjęty przez nich temat został powoli urzeczywistniany i znalazł swoje dopełnienie w historycznej koncepcji Augustyna. Ambroży przeprowadza sekularyzację historii, lecz chciałby jeszcze, aby resztka zasady skuteczności nadal obowiązywała. Augustyn nie tylko sekularyzował; on odebrał historii wszelką zdolność badawczą, wszelką własną wartość. Ambroży ogłosił Chrystusa panem dziejów, Augustyn umiejscowił civitas Dei po tamtej stronie historii.

Przedstawione uwagi można by krótko tak zebrać. Dzięki obu autorom, Ambrożemu i Augustynowi, dopełniło się w latach 380 - 410, a więc w czasie dość krótkim, przekształcenie antycznej teorii historii. Zasada skuteczności została nie tylko doprowadzona faktycznie do absurdu przez nieuregulowaną sytuację zewnętrzną cesarstwa, lecz także została prześcignięta przez teologi-

${ }^{41}$ A ugustinus, In loannis epistulam ad Partos tractatus $X$ 8,9 (PL 35 s. 2041)

${ }^{42}$ Zob. W. Ge erlings, Christus Exemplum..., s. 220 n.

${ }^{43}$ Zob. A u gust in us, De civitate Dei, XX 10 (CCL 48 s. 714). 
czną argumentację. Zasada skuteczności, tak jak ona ujawniła się w przykładach, była jednocześnie ściśle związana z religijnym wyobrażeniem wielu kompetencyjnych bogów. Monoteizm o żydowsko-chrześcijańskiej proweniencji nie mógł zgodzić się na historyczno-teologiczną zasadę skuteczności z racji swojej wewnętrznej logiki, ponieważ wtedy musiałby tolerować segmentarną kompetencję poszczególnych bogów. Przemiana antycznej teologii historii wskazuje jednocześnie na przejście do nowego pojęcia Boga. Że dokonało się to porywczo i w dość krótkim czasie, ukazuje wewnętrzna konsekwencja tego procesu. Zasada objawienia usunęła zasadę skuteczności. „Szkaradny rów historii" pozostanie odtąd problemem chrześcijańskiej teologii. To, co jest umieszczone poza historią - by znowu sięgnąć do Augustyna - „zostanie zrozumiane tylko przez tych, który są czystego serca" ${ }^{44}$.

Ttumaczyt: Roman Zawadzki

${ }^{44}$ Zob. wyżej przypis 39. 